Int. J. Electrochem. Sci., 14 (2019) $10592-10606$

\title{
Global Sensitivity Analysis of a Microbial Fuel Cell Model
}

\author{
Yankai Yin ${ }^{1}$, Chengcai Fu ${ }^{2}$, Fengying $\mathrm{Ma}^{1, *}$ \\ ${ }^{1}$ School of Electrical Engineering and Automation, Qilu University of Technology, Jinan 250100, P R \\ China \\ ${ }^{2}$ School of Mechanical Electronic \& Information Engineering, China University of Mining \& \\ Technology, Beijing 100083, P R China \\ *E-mail: mafengy@,163.com
}

doi: $10.20964 / 2019.11 .55$

Received: 7 April 2019 / Accepted: 7 September 2019 / Published: 7 October 2019

The global sensitivity method based on variance was applied to the microbial fuel cell (MFC) field for the first time here. The purpose of this study was to expound how the global sensitivity method can be used in the mathematical model of MFC and to visualize the sensitivity index of eight key parameters, such as the flow rate of the fuel feed, with respect to the MFC power performance. This algorithm can not only clarify the influence of uncertain parameters on power density, but also explain the influence of the interaction of uncertain parameters on MFC power density. The result shows that the cathodic charge transfer coefficient, acetate concentration in the influent of the anode chamber, forward rate constant of anode reaction under standard conditions, half velocity rate constant for acetate, charge transfer coefficient of the anode, forward rate constant of the cathode reaction under standard conditions and flow rate of the fuel feed to the anode are sensitive parameters that affect the power density of MFC; furthermore, the cathodic charge transfer coefficient is the most influential. Additionally, it was found that the electrical conductivity of the aqueous solution in MFC is the least sensitive parameter. The research achievements in this paper can be used in model optimization, parameter analysis or model simplification.

Keywords: global sensitivity; microbial fuel cell; variance-based method; electrochemical model

\section{FULL TEXT}

(C) 2019 The Authors. Published by ESG (www.electrochemsci.org). This article is an open access article distributed under the terms and conditions of the Creative Commons Attribution license (http://creativecommons.org/licenses/by/4.0/). 